\title{
MARKETING TOOLS IN STRATEGIC MANAGEMENT OF YOUNG SCIENTISTS' HUMAN CAPITAL
}

\author{
Iuliia Gernego' ${ }^{1}$, Tetiana Shkoda², Oleksandr Savych ${ }^{3}$
}

\begin{abstract}
The purpose of the paper is to identify the marketing tools, which are promising areas of functional provision of strategic management of young scientists' human capital in Ukraine. The novelty of the research is represented by the created theoretical model of the conceptual scenario of strategic management of young scientists' human capital. The object of the scientific research is the process of using marketing tools in strategic management of young scientists' human capital. The research methodology includes such methods: comparative analysis, critical analysis, statistical analysis, economic-mathematical analysis and graph-analytical. The research is based on the results of mass sociological survey of young scientists in Ukraine performed within the framework of the project "Realization of the young scientists' potential in integration of science, education, and business" (0120U102126) in 2020 year. The obtained results confirmed fully the proposed hypothesis $\mathrm{H}_{1}$ and $\mathrm{H}_{2}$ and partially the hypothesis H3. The discussion section of the paper proposes the improved method of evaluating the human potential of young scientists, which includes four vectors: assessment of business qualities of educational managers, evaluation of the effectiveness of the organizational structure of management of scientific and educational institutions, assessment of the overall effectiveness of marketing activities of scientific and educational institutions, general evaluation of marketing potential of human development in the strategic management of human capital of research and educational institutions. The fourth component is proposed to produce marketing tools used by young scholars based on the results of a mass sociological survey. The practical value of the proposed instruments for the young scientists' community and scientific and educational institutions, where they are employed, is in the use of the adapted graph-analytical method, which gives the opportunity to assess the marketing tools in strategic management of young scientists' human capital.
\end{abstract}

Key words: marketing tools, strategic management, human capital, young scientists.

JEL Classification: 123, J24, M31

\section{Introduction}

The connection between the community of young scientists and society creates a necessary condition for increasing the interest of young scientists in realizing their potential in the scientific field. Currently, the lack of popularization of science and education, and the low prestige of the scholarly profession in Ukraine create a measure of factors that affect the low attractiveness of science (Zhabin, Isakova, Skorokhod, 2018) as an area of professional realization for young researchers. According to Ukrainian legislation, the category of young scientists includes those under the age of 35 for $\mathrm{PhD}$ and researchers without scientific degree or under the age of 40 for doctors of science (Parliament of Ukraine, 2015).

In accordance with the need to ensure the successful resolution of the above-mentioned problems about the development potential of young scientists, it is important to use marketing tools in the process of strategic management of young scientists' human capital. In particular, an important feature of the

\footnotetext{
Corresponding author:

${ }^{1}$ Kyiv National Economic University named after Vadym Hetman, Ukraine.

E-mail: iuliiagern@ukr.net

ORCID: https://orcid.org/0000-0002-4929-0411

ResearcherID: G-7178-2017

${ }^{2}$ Kyiv National Economic University named after Vadym Hetman, Ukraine.

E-mail: tnshkoda@ukr.net

ORCID: https://orcid.org/0000-0003-1016-4853

ResearcherID: M-1847-2013

${ }^{3}$ Kyiv National Economic University named after Vadym Hetman, Ukraine.

E-mail: savych@kneu.edu.ua

ORCID: https://orcid.org/0000-0001-5934-9002

ResearcherID: AAL-1229-2020
} 
use of marketing tools in realizing the potential of a young scientist is its innovative basis, which implies the use of modern tools to promote professional achievements.

The COVID-19 pandemic has significantly affected the scientific communication among young scientists and its features. Thereby, in May 2020, during the strict COVID-19 quarantine in Ukraine, the Council of Young Scientists at the Ministry of Education and Science of Ukraine conducted a survey (CYS at MESU, 2020), which showed that $84.6 \%$ of young scientists in Ukraine used such an opportunity as preparation of a scientific publication. The second most important marketing tool was participation in an online scientific conference (54.0\%). This study emphasizes the interest of public authorities in the effective strategic management of human capital of young scientists, which contributes to strengthening the positive image of Ukrainian science and education in the world and the practical implementation of state documents such as the Strategy of Higher Education of Ukraine for 2021-2031 (MESU, 2020), one of the objectives of which is to enhance the status of employees of educational institutions in society and stimulate their professional development, including young scientists

\section{Literature review on the place of marketing tools in strategic human capital management}

Recently, research and educational institutions as organizations are interested in the long-term, strategic perspective of human capital management. This creates the reason to particularly increase the importance of the process of forming a human capital management strategy.

The human capital management strategy determines the expected growth dynamics of the organization, key indicators of success and satisfies the needs arising from the current stage of growth (Roskowski, 2003). In the process of research of human capital management strategy it is reasonable to consider this strategy as a plan indicating the direction of movement of enterprises in the field of human capital management. It is aimed at achieving certain goals with rational commercialization of human potential, the necessary level of art effect and elasticity of strategic management decision.

In accordance with the above definition, it is also important to note that human capital management strategy refers to dynamic strategies. Thus, according to L. Frolova and T. Nosova (Frolova, Nosova, 2015), the dynamic strategy characterizes the change of dynamic equilibrium of the system "enterprise environment", namely the process of its quantitative and qualitative changes for a certain period of time. This interpretation, taking into account the influence of the external environment, coincides with our understanding of the importance of the analysis of the poly-subject environment in the conceptual scenario of strategic management of human capital of young scientists, where, in particular, such component of the poly-subject environment as the market environment, is external in relation to the organization.

The use of marketing tools in strategic human capital management already represents a stage of practical implementation of human capital management strategy. At the same time, the whole process of strategic human capital management on the example of the target group of young scientists reflects the conceptual scenario, which includes several stages: 1) conceptual; 2) scenario; 3) implementation. Representation of such conceptual scenario of strategic management of human capital is presented in Figure 1.

In particular, the conceptual stage includes: selection of management subjects; development of an appropriate scientific concept of strategic management of human capital (Shkoda, 2018), which should be enshrined in the appropriate document of strategic development of young scientists; analysis of the polysubject environment; definition of the current vision and system limitations. At the scenario stage a suitable variant of human capital management strategy is selected using a scenario model of human capital management strategy selection, defining strategic goals and objectives, as well as objects of management.

The realization stage of the conceptual scenario is the main within the framework of our study, because it includes the justification and forecasting in the areas of functional support of strategic management of human capital, which includes the marketing area. In particular, it includes: marketing of the product, price, promotion, distribution and personnel. In accordance with these components, the purpose of our study is to identify the marketing tools most appropriate for the effective implementation of marketing policy in the process of strategic management of young scientists' human capital.

In particular, among the current marketing trends, researchers highlight digitalization and strengthening of online communication with customers (Radionova-Girsa, 2018). For instance, during the COVID-19 pandemic (Hoekstra, Leeflang, 2020), the use of multichannel marketing to enhance personalization with consumers (Reshetnikova, Smerichevsky, Polishchuk, 2019), the increasing influence of globalization and digitalization (Savych, Shkoda, 2020), the formation of a new paradigm of strategic marketing and market reformatting (Dligach, 2014). The growing role of Internet marketing nowadays is seen by some scholars as a third communication revolution that enables organizations to communicate freely with their target audience regardless of location and time (Scott, 2017). 


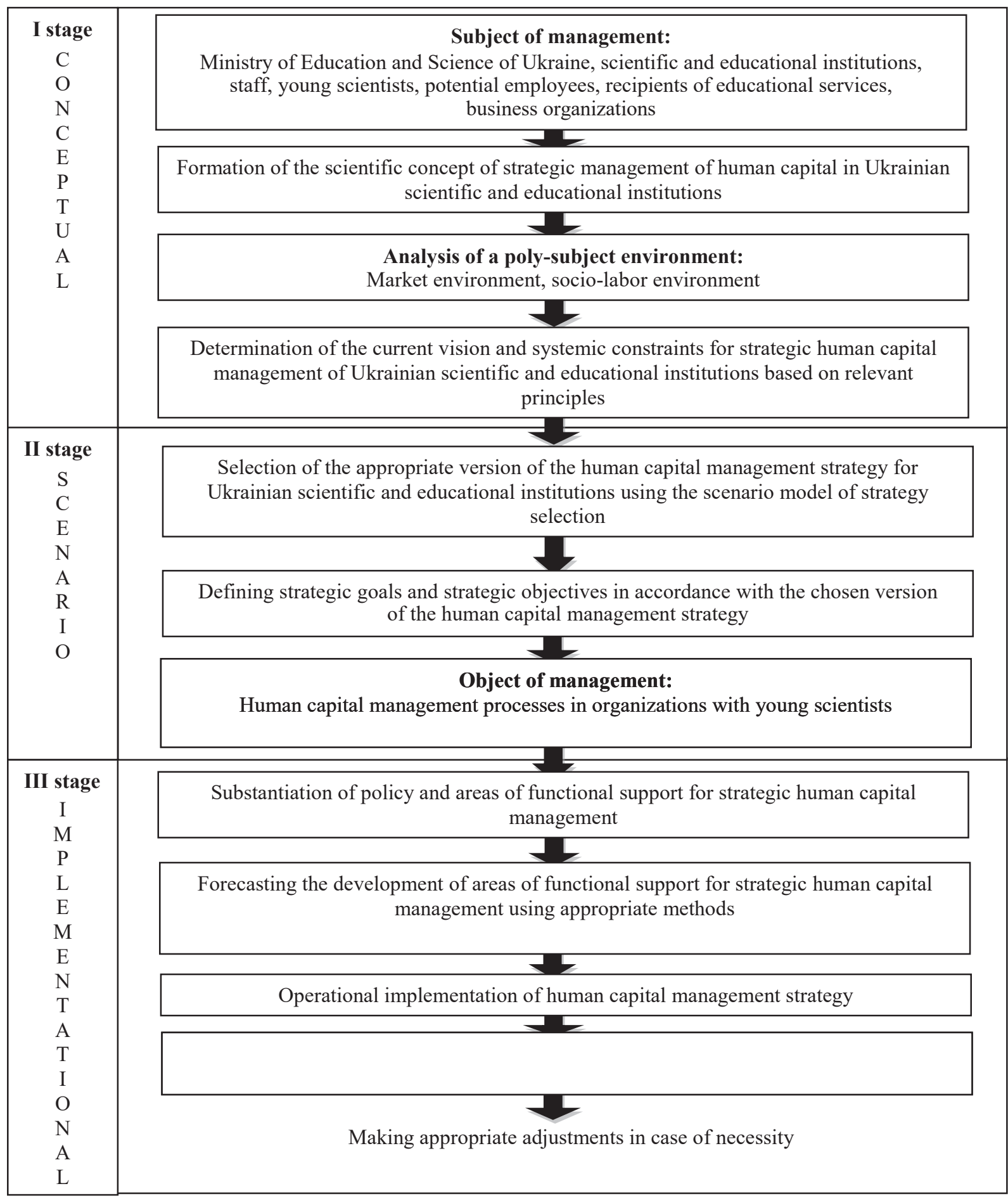

Figure 1. Conceptual scenario for young scientists' human capital strategic management

Source: composed by the authors

Choosing the right set of marketing mix or combining numerous marketing tools is important to find contact with the target audience (Sturiene, 2019). The influence of such an indirect marketing tool as corporate social responsibility is also growing (Bhattacharya, Good, Sardashti, 2020). In particular, it corresponds to the emergence and increasing dissemination of the Concept of Sustainable
Development for the selection of appropriate marketing tools (Csapo-Horvath, 2021) to implement the process of strategic human capital management of young scientists, including Sustainable Development Goal 4 "Quality Education" (Gernego, 2020; Irtyshcheva, Trushliakova, Sirenko, 2020).

In marketing, at its current stage of development, the following trends are considered most important 
for young scientists, namely: adaptation of tools for the promotion of young scientists to digital technologies, digitalization of marketing communications of young scientists, increasing the combination of offline and online participation of young scientists in scientific conferences and forums, direct communication with business, which is important for professional success of young scientists, increasing the involvement of young scientists in socially responsible activities. These trends are characteristic of such a component of the marketing complex as marketing promotion.

In accordance with the above mentioned research, it is advisable to put forward the following hypotheses of our study, taking into account the specifics of marketing:

$\mathrm{H}_{1}$ - the most effective marketing tools in the process of strategic management of young scientists' human capital are digital marketing promotion tools;

$\mathrm{H}_{2}$ - the majority of young scientists in Ukraine do not use cooperation with business as a marketing tool for promotion, which negatively affects the commercialization of the results of their intellectual activity in the process of strategic human capital management;

$\mathrm{H}_{3}$ - the use of popular science articles as a marketing tool to promote science is most common among young scholars, hence the most effective.

Verification of the hypotheses put forward in this study will make it possible to draw appropriate conclusions about the prospects of using appropriate marketing promotion tools in the process of strategic management of the human capital of young scientists.

\section{Methodology}

The main methods used in this study are as follows: 1) comparative and critical analysis for the theoretical part; 2) statistical analysis to substantiate the results of the study; 3 ) economic and mathematical modeling to determine the relationship of the components of the discussion part; 4) graph-analytical method - to visualize the provisions of the work.

The study of marketing tools used by young scientists to realize their potential, and useful for scientific and educational institutions in the context of strategic management of human capital of young scientists, was carried out in 2020 as part of the mass survey of young scientists conducted by of the young scientists' team of the project "Realization of the young scientists' potential in integration of science, education, and business", with the support of the Council of Young Scientists of Ukraine. The general population of the study is 11,500 young scientists in Ukraine (State Statistical Service of Ukraine, 2020). Number of completed questionnaires - 579, of which 10 questionnaires were rejected. Confidence probability (accuracy) - 95\%, error - 5\% (required sample size - 372). The sample is representative of the whole of Ukraine. The stratification principle was used in the construction of the sample. The regions of Ukraine were taken as the stratums.

Table 1

Respondents' answers to the question "In your opinion, what are the most effective ways to promote information about your own research and development?"

\begin{tabular}{|c|c|c|c|c|}
\hline & \multicolumn{3}{|c|}{ Your scientific degree } \\
\hline & & \multirow{2}{*}{$\begin{array}{c}\text { Doctor of science } \\
\% \text { per column } \\
\end{array}$} & \multirow{2}{*}{$\begin{array}{c}\text { Candidate of } \\
\text { science }(\mathrm{PhD}) \\
\% \text { per column }\end{array}$} & \multirow{2}{*}{$\begin{array}{c}\text { Without scientific } \\
\text { degree }\end{array}$} \\
\hline & & & & \\
\hline \multirow{12}{*}{$\begin{array}{l}\text { In your opinion, what } \\
\text { are the most effective } \\
\text { ways to promote } \\
\text { information about } \\
\text { your own research and } \\
\text { development }\end{array}$} & Participation in conferences and forums & $83,9 \%$ & $76,3 \%$ & $75,2 \%$ \\
\hline & $\begin{array}{l}\text { Publications in journals, publications of } \\
\text { educational institutions and research institutes }\end{array}$ & $67,9 \%$ & $57,2 \%$ & $59,0 \%$ \\
\hline & $\begin{array}{l}\text { Publication of own manuals, monographs, } \\
\text { methodical materials }\end{array}$ & $48,2 \%$ & $35,8 \%$ & $28,8 \%$ \\
\hline & $\begin{array}{l}\text { Internet projects of scientific, social, technical } \\
\text { subjects }\end{array}$ & $21,4 \%$ & $33,4 \%$ & $43,2 \%$ \\
\hline & $\begin{array}{l}\text { Competitions of scientific works, innovative } \\
\text { projects, social initiatives }\end{array}$ & $42,9 \%$ & $34,4 \%$ & $32,4 \%$ \\
\hline & Media & $21,4 \%$ & $23,1 \%$ & $31,1 \%$ \\
\hline & Social networks & $28,6 \%$ & $42,8 \%$ & $46,4 \%$ \\
\hline & Exhibitions, investment forums & $17,9 \%$ & $27,1 \%$ & $26,1 \%$ \\
\hline & $\begin{array}{l}\text { Public hearings, round tables with government } \\
\text { officials and the real sector }\end{array}$ & $23,2 \%$ & $25,1 \%$ & $28,8 \%$ \\
\hline & $\begin{array}{l}\text { Articles in publications of authorities, of the real } \\
\text { sector representatives (enterprises) }\end{array}$ & $14,3 \%$ & $13,7 \%$ & $14,9 \%$ \\
\hline & Other & $5,4 \%$ & $3,0 \%$ & ,9\% \\
\hline & $\mathrm{N} / \mathrm{a}$ &, $0 \%$ &, $0 \%$ &, $0 \%$ \\
\hline
\end{tabular}

Source: composed by the authors 
Table 2

Respondents' answers to the question "Do you promote science? Write exactly how"

\begin{tabular}{|c|c|c|c|c|}
\hline & & \multicolumn{3}{|c|}{ Your scientific degree } \\
\hline & & Doctor of science & $\begin{array}{c}\text { Candidate of } \\
\text { science }(\mathrm{PhD})\end{array}$ & $\begin{array}{c}\text { Without scientific } \\
\text { degree }\end{array}$ \\
\hline & & $\%$ per column & $\%$ per column & $\%$ per column \\
\hline \multirow{9}{*}{$\begin{array}{l}\text { Do you promote science? } \\
\text { Write exactly how }\end{array}$} & No, I don't & $21,8 \%$ & $25,5 \%$ & $32,0 \%$ \\
\hline & Popular science articles & $32,7 \%$ & $46,3 \%$ & $31,5 \%$ \\
\hline & Speeches in the media & $29,1 \%$ & $16,1 \%$ & $13,2 \%$ \\
\hline & Public lectures & $23,6 \%$ & $26,5 \%$ & $21,9 \%$ \\
\hline & Activity in Internet & $23,6 \%$ & $33,6 \%$ & $36,5 \%$ \\
\hline & Sports and entertainment events & $7,3 \%$ & $9,1 \%$ & $5,9 \%$ \\
\hline & Small Academy of Sciences & $14,5 \%$ & $12,1 \%$ & $7,8 \%$ \\
\hline & Other & $12,7 \%$ & $5,4 \%$ & $5,0 \%$ \\
\hline & $\mathrm{N} / \mathrm{a}$ & $1,8 \%$ &, $0 \%$ & $0 \%$ \\
\hline
\end{tabular}

Source: composed by the authors

Table 3

Respondents' answers to the question

"How many times a year do you participate offline at scientific conferences and forums in Ukraine?" and "How many times a year do you participate offline at scientific conferences, forums abroad?"

\begin{tabular}{|l|c|c|c|}
\hline \multirow{2}{*}{} & \multicolumn{3}{|c|}{ Your scientific degree } \\
\cline { 2 - 4 } & Doctor of science & Candidate of science (PhD) & Without scientific degree \\
\cline { 2 - 4 } & In average & In average & In average \\
\hline $\begin{array}{l}\text { How many times a year do you participate offline } \\
\text { at scientific conferences and forums in Ukraine? }\end{array}$ & 3,29 & 2,46 & 1,90 \\
\hline $\begin{array}{l}\text { How many times a year do you participate offline } \\
\text { at scientific conferences, forums abroad? }\end{array}$ & 1,09 &, 74 &, 48 \\
\hline
\end{tabular}

Source: composed by the authors

Table 4

Respondents' answers to the question

"Do you have contacts with foreign colleagues? How well do you know the experts?"

\begin{tabular}{|c|c|c|c|c|}
\hline & & \multicolumn{3}{|c|}{ Your scientific degree } \\
\hline & & $\begin{array}{c}\text { Doctor of } \\
\text { science }\end{array}$ & $\begin{array}{c}\text { Candidate of } \\
\text { science }(\mathrm{PhD})\end{array}$ & $\begin{array}{c}\text { Without } \\
\text { scientific degree }\end{array}$ \\
\hline & & $\%$ per column & $\%$ per column & $\%$ per column \\
\hline \multirow{9}{*}{$\begin{array}{l}\text { Do you have contacts } \\
\text { with foreign colleagues? } \\
\text { How well do you know } \\
\text { the experts? }\end{array}$} & No & $7,3 \%$ & $26,2 \%$ & $45,2 \%$ \\
\hline & Know their works & $36,4 \%$ & $37,9 \%$ & $35,3 \%$ \\
\hline & Know their works and communicate on conferences & $38,2 \%$ & $29,5 \%$ & $13,6 \%$ \\
\hline & Know their works and support exchange of information & $29,1 \%$ & $20,1 \%$ & $12,7 \%$ \\
\hline & Know their works and have common publications & $38,2 \%$ & $16,8 \%$ & $7,7 \%$ \\
\hline & Have experience of joint teaching activities & $7,3 \%$ & $2,7 \%$ & $4,5 \%$ \\
\hline & Have experience in joint research projects & $25,5 \%$ & $14,4 \%$ & $9,5 \%$ \\
\hline & Other & $1,8 \%$ &, $7 \%$ &, $5 \%$ \\
\hline & $\mathrm{N} / \mathrm{a}$ &, $0 \%$ &, $0 \%$ &, $0 \%$ \\
\hline
\end{tabular}

Source: composed by the authors

The respondents from all regions of Ukraine were interviewed. At the same time, a third of respondents are from Kyiv (33.5\%). Kharkiv, Lviv, and Dnipro regions, which have significant research and university centers, rank second in the number of respondents.

The general characteristics of the young Ukrainian scientists who participated in the study are as follows: $67.9 \%$ of the respondents are women, $61.5 \%$ of the surveyed young scientists have a scientific degree and $24 \%$ have a scientific title.

When developing the research form, the questions related to the marketing components were not singled out as a separate block. Specifically, the questionnaire contained blocks such as: 1) general information; 2) financial support; 3) professional activities; 4) international cooperation and academic mobility; 5) academic entrepreneurship; and 6) academic 
policy/open-ended questions. Within these blocks, respondents were asked a series of questions reflecting the marketing promotional tools that both young scientists and their educational and research institutions use in the strategic management of their human capital.

\section{Results. Marketing tools \\ at the implementation stage \\ of strategic management \\ of young scientists' human capital}

The detailed analysis of the Questionnaire for young scientists of Ukraine in the project "Realization of young scientists' potential in the integration of science, education, and business" makes it possible to determine which practical marketing tools are most effective in the process of strategic human capital management of young scientists.

For example, the statistics of the respondents' answers to the question "In your opinion, what are the most effective ways to promote information about your own research and development?" is presented in Table 1.

According to the results of the survey presented in Table 1, among all three groups of young scientists (doctor of sciences under 40, candidate of science $(\mathrm{PhD})$ under 35, researcher without a degree under 35) the most popular tools to promote information about their own research and development are participation in conferences and forums (83.9\%; 76.3\%; 75.2\% accordingly), and publications in journals, publications of

Table 5

Respondents' answers to the question "How many times a year do you take part in public events/events on socially responsible topics (for example, environmental, human rights, educational, where you participate on a volunteer basis)?"

\begin{tabular}{|l|c|c|c|}
\hline \multirow{2}{*}{} & \multicolumn{3}{|c|}{ Your scientific degree } \\
\cline { 2 - 4 } & Doctor of science & $\begin{array}{c}\text { Candidate of science } \\
\text { (PhD) }\end{array}$ & $\begin{array}{c}\text { Without scientific } \\
\text { degree }\end{array}$ \\
\cline { 2 - 4 } & In average & In average & In average \\
\hline $\begin{array}{l}\text { How many times a year do you take part in public events/events } \\
\text { on socially responsible topics (for example, environmental, human } \\
\text { rights, educational, where you participate on a volunteer basis)? }\end{array}$ & 3,66 & 2,91 & 3,06 \\
\hline
\end{tabular}

Source: composed by the authors

Table 6

Respondents' answers to the question "Do you have experience of cooperation with business?"

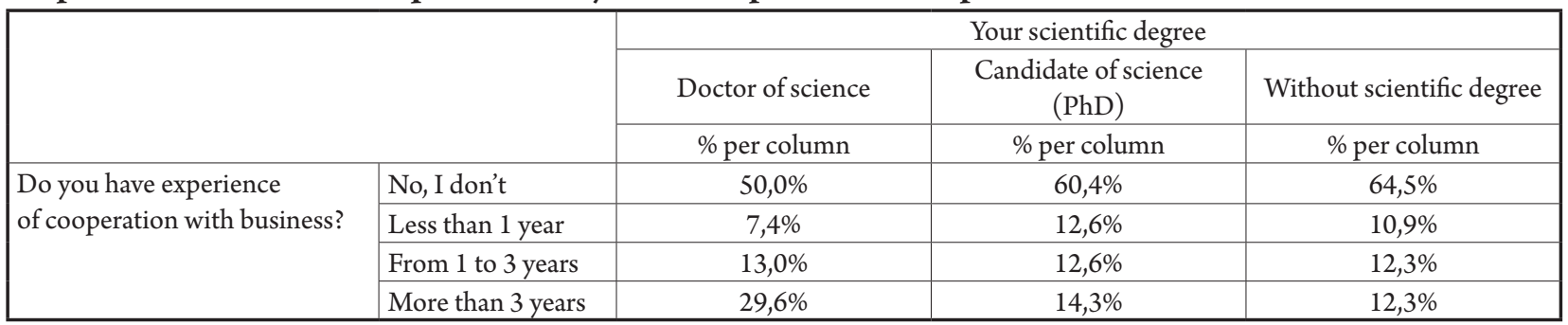

Source: composed by the authors

Table 7

Respondents' answers to the question "Do you have experience in commercializing the rights to the results of your intellectual activity? Where?"

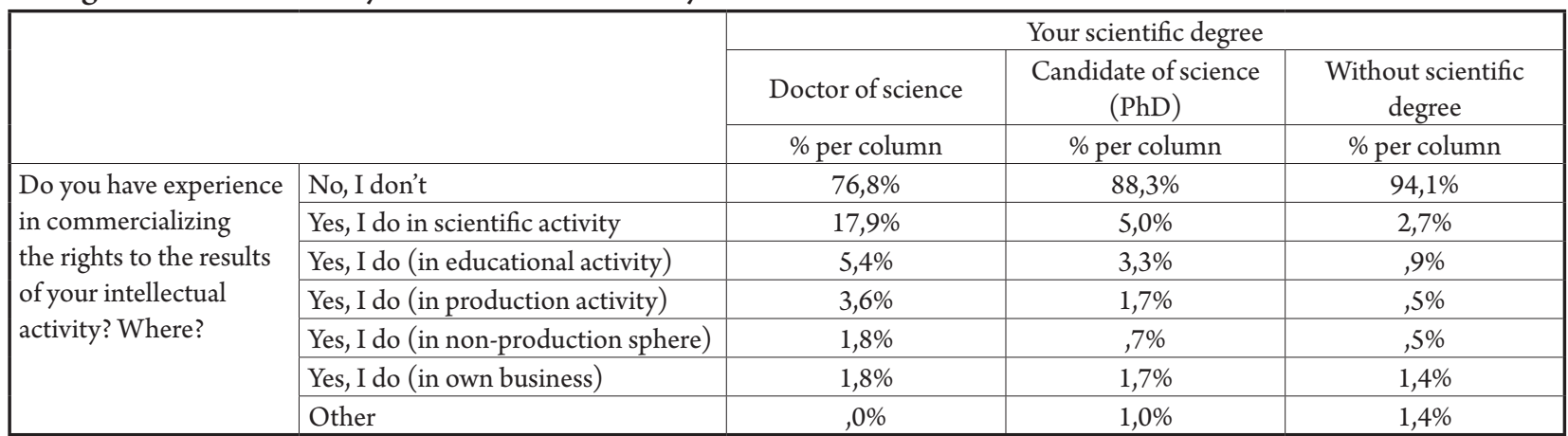

Source: composed by the authors 
Vol. 7 No. 4, 2021

Table 8

Business qualities of educational managers' assessment

\begin{tabular}{|c|l|c|c|}
\hline № & \multicolumn{1}{|c|}{ Managers' qualities } & Validity & Estimation \\
\hline 1 & \multicolumn{1}{|c|}{2} & 3 & 4 \\
\hline 1 & Business (education, knowledge, practical experience) & 0,15 & \\
\hline 2 & Opportunities (talent, genius) & 0,15 & \\
\hline 3 & Cultural qualifications and erudition, honesty and decency & 0,1 & \\
\hline 4 & Character (will, activity, obligation, efficiency, care for subordinates) & 0,15 & \\
\hline 5 & Priority temperament (choleric, sanguine, phlegmatic, melancholic) & 0,1 & \\
\hline 6 & Direction of interests (material, social, spiritual) & 0,1 & \\
\hline 7 & Age qualification (young, average, elderly) & 0,1 & \\
\hline 8 & Health (good, satisfactory, bad) & 0,15 & \\
\hline 9 & The average estimation of business qualities & & \\
\hline
\end{tabular}

Source: composed by the authors

educational institutions and research institutes (67.9\%; 57.2\%; 59.0\% respectively). Interestingly, such a modern marketing tool as social media is quite popular among $\mathrm{PhD}$ candidates $(42.8 \%)$ and researchers without a degree $(46.4 \%)$, but not very important for young doctors of science $(28.6 \%)$. In addition, Internet projects of scientific, social and technical topics are used by respondents to promote their own research and development in the following proportions: $21.4 \%, 33.4 \%$ and $43.2 \%$, respectively. It should be noted that digital tools are used by all categories of young scientists, but with different frequency. So, it can be considered as the proof of the authors' research hypothesis $H_{1}$.

According to Table 2, $76.4 \%$ of young doctors of science, $74.5 \%$ of candidates of science (PhD) under the age of 35 and $68 \%$ of researchers without a scientific degree are engaged in popularization of science. The obtained data partially confirm the authors' hypothesis $\mathrm{H}_{3}$, because for the latter group activity on the Internet $(36.5 \%)$ is a more effective way to promote science than popular science articles, which are most often used as a marketing tool by young scientists who are doctors of science (32.7\%) and candidates of science (46.3\%). It also partially confirms the authors' hypothesis $H_{1}$ that the most effective marketing tools in the process of strategic management of human capital of young scientists are digital tools for marketing promotion.

The format of respondents' participation in conferences and forums also needs further clarification. The results of the answer to this question are presented in Table 3.

Young scientists make little use (on average, once a year for all groups) of such a marketing tool as offline participation in scientific conferences and forums to promote their own research results, which also partially confirms the $H_{1}$ hypothesis. Most often among the surveyed respondents this is done by young doctors of science, who do it on average 3 times a year.
However, according to Table 4, a significant proportion of young scientists know the works of their foreign colleagues and communicate with them at conferences $(38.2 \% ; 29.5 \% ; 13.6 \%$, respectively, in groups), i.e. have the opportunity to do so online. At the same time, researchers without a degree generally have the least opportunities to contact foreign colleagues $-45.2 \%$.

Young doctors of science are most likely to be able to popularize science through such a tool as research projects, as $25.5 \%$ of them have experience in collaborative research projects with foreign colleagues. Similarly, $38.2 \%$ of the group of young doctors of science have joint publications with foreign colleagues, while for researchers without a degree, this figure is only $7.7 \%$.

The results obtained (Table 5) show that among young scientists in Ukraine such a marketing tool as the use of social responsibility is not very pronounced, as on average respondents participate in events on socially responsible topics 3 times a year, which in general is only $17 \%$ of the surveyed young scientists.

The state of young scientists' use of such a marketing tool as collaboration with stakeholders, namely business, is shown in Table 6 and Table 7 .

The vast majority of young scientists have no experience of cooperation with business. The highest this disappointing figure is among researchers without a degree and is $64.5 \%$. Young doctors of science have the most practical experience of cooperation with business for more than 3 years $-29.6 \%$.

The vast majority of young scientists in all three groups have no experience of commercializing the rights to the results of their intellectual activity (76.8\%; 88.3\%; 94.1\%, respectively). This almost completely limits the use of marketing tools to promote commercialized intellectual products of young scientists as a result of the realization of their human capital. Thus, we have a full confirmation of the authors' hypothesis $\mathrm{H}_{2}$. 


\section{Discussion}

Modern vision and system limitations of strategic management of human capital of scientific and educational institutions of Ukraine is formed through the proposal to assess the potential of human development on the example of a professional group of young scientists. In the context of this study, the evaluation of human development potential is based on the study in accordance with the elements of graphanalytical method of analysis "Square of potential" (Fedonin, Riepina, Oleksiuk, 2006). In particular, the following groups of indicators were selected for the purposes of the current analysis, namely: assessment of business qualities of educational managers from the professional group of young scientists (indicator 1), efficiency of organizational structure of management of scientific and educational institutions (indicator 2), overall efficiency of marketing activities (indicator 3), marketing potential of human development in strategic management of human capital (indicator 4).

The group of indicators of organizational structure and management is assessed through the business qualities of educational managers (Table 8) according to the following scale: present -1 point; too rare 2 points; not strong and not weak -3 points; often 4 points; systematically -5 points.

The average estimation of business qualities is conducted in accordance with the formula 1.

$$
K_{m}=\frac{\sum_{i=1}^{n} \sum_{j=1}^{k} \alpha_{j} \beta_{i j}}{n},
$$

where $K_{m}$ - the average indicator of business qualities of managers, points;

$i=1,2,3, \ldots, n$ - number of experts;

Table 9

Evaluation of the effectiveness of the organizational management structure of scientific and educational institutions

\begin{tabular}{|c|c|c|c|c|}
\hline № & Question & The company profile & Validity & Estimation \\
\hline 1 & $\begin{array}{l}\text { Do the institutions work with } \\
\text { purpose? }\end{array}$ & $\begin{array}{l}\text { Institutions have strategic and tactical goals that are } \\
\text { developed independently. }\end{array}$ & & \\
\hline 2 & $\begin{array}{l}\text { Is the flexibility of institutions } \\
\text { sufficient? }\end{array}$ & The speed of response of institutions to change. & & \\
\hline 3 & $\begin{array}{l}\text { Is the organizational structure } \\
\text { clearly visible? }\end{array}$ & $\begin{array}{l}\text { Institutions have a diagram of the structure of the } \\
\text { organization, a description of the relevant functions } \\
\text { and procedures. }\end{array}$ & & \\
\hline 4 & $\begin{array}{l}\text { Is there enough delegated } \\
\text { power? }\end{array}$ & $\begin{array}{l}\text { There is freedom in decision-making at different } \\
\text { levels of government, but within the limits of their } \\
\text { delegated authority. }\end{array}$ & & \\
\hline 5 & $\begin{array}{l}\text { Do institutional management } \\
\text { have enough time to discuss } \\
\text { strategic objectives? }\end{array}$ & $\begin{array}{l}\text { Involvement of managers in strategic and tactical } \\
\text { issues. }\end{array}$ & & \\
\hline 6 & $\begin{array}{l}\text { Is there a spirit of cooperation in } \\
\text { the institutions? }\end{array}$ & $\begin{array}{l}\text { In institutions, "corporate" psychology, activities } \\
\text { aimed at cooperation }\end{array}$ & & \\
\hline 7 & $\begin{array}{l}\text { Do managers have enough } \\
\text { information? }\end{array}$ & $\begin{array}{l}\text { There is a unified database and communication } \\
\text { system that allows you to quickly learn about the } \\
\text { latest developments and make decisions according } \\
\text { to the existing prerequisites. }\end{array}$ & & \\
\hline
\end{tabular}

Source: composed by the authors

Table 10

Evaluation of the overall effectiveness of research and educational institutions marketing activities

\begin{tabular}{|c|l|c|c|}
\hline$№$ & \multicolumn{1}{|c|}{ Indicator } & Validity & Estimation \\
\hline 1 & \multicolumn{1}{|c|}{2} & 3 & 4 \\
\hline 1 & Corporate identity (developed areas) & & \\
\hline 2 & Adaptation to conditions of unstable environment, points & & \\
\hline 3 & Weak competitive pressure, points & & \\
\hline 4 & Consumer commitment, points & & \\
\hline 5 & Marketing strategies, points & & \\
\hline 6 & Objectives of the enterprise, points & & \\
\hline 7 & Opportunities to penetrate new markets, points & & \\
\hline The average estimation of qualities & & \\
\hline
\end{tabular}

Source: composed by the authors 
Table 11

General assessment of the marketing potential of human development in the strategic management of human capital of research and educational institutions

\begin{tabular}{|c|l|c|c|}
\hline$№$ & \multicolumn{1}{|c|}{ Indicator } & Validity & Estimation \\
\hline 1 & \multicolumn{1}{|c|}{2} & 3 & 4 \\
\hline 1 & Participation in conferences and forums & & \\
\hline 2 & Publications in journals, publications of educational institutions and research institutes & & \\
\hline 3 & Publication of own manuals, monographs, methodical materials & & \\
\hline 4 & Internet projects of scientific, social, technical subjects & & \\
\hline 5 & Competitions of scientific works, innovative projects, social initiatives & & \\
\hline 6 & Media & & \\
\hline 7 & Social networks & & \\
\hline 8 & Exhibitions, investment forums & & \\
\hline 9 & Public hearings, round tables with government officials and the real sector & & \\
\hline 10 & Publications in publications of authorities, of the real sector representatives (enterprises) & & \\
\hline 11 & CSR events & & \\
\hline The average estimation of qualities & & \\
\hline
\end{tabular}

Source: composed by the authors

$j=1,2,3, \ldots, k-$ the number of proposed qualities of managers;

$\alpha_{i}, \beta_{j}$ - weight of the $\mathrm{j}$-th quality of managers and evaluation of the $j$-th quality by the $i$-th expert.

The algorithm of Table 9 is used to assess the effectiveness of the organizational structure of domestic scientific and educational institutions management.

The study of the general marketing component of the human development potential of scientific and educational institutions is carried out by means of an overall assessment, which is presented in Table 10 .

An overall assessment was made to study the component of the marketing potential of human development in the strategic management of human capital of research and educational institutions. The studies studied are presented in Table 11.
Schedule of vectors estimated by average estimations (Tables 8-11) is represented within the Figure 2.

The obtained ratios of the components of the potential of the subjects under study allow us to determine at what level each component is, and therefore to identify the corresponding relationships between the levels of different vectors (Figure 2) and to decide which vectors to develop further.

Thus, the proposed methodology makes it possible to assess the prospects of human potential development of scientific and educational institutions in which young scientists work. In particular, one of the four important components of the discussed methodology is the marketing of human development potential in the strategic human capital management of domestic scientific and educational institutions. Its elements

IV vector

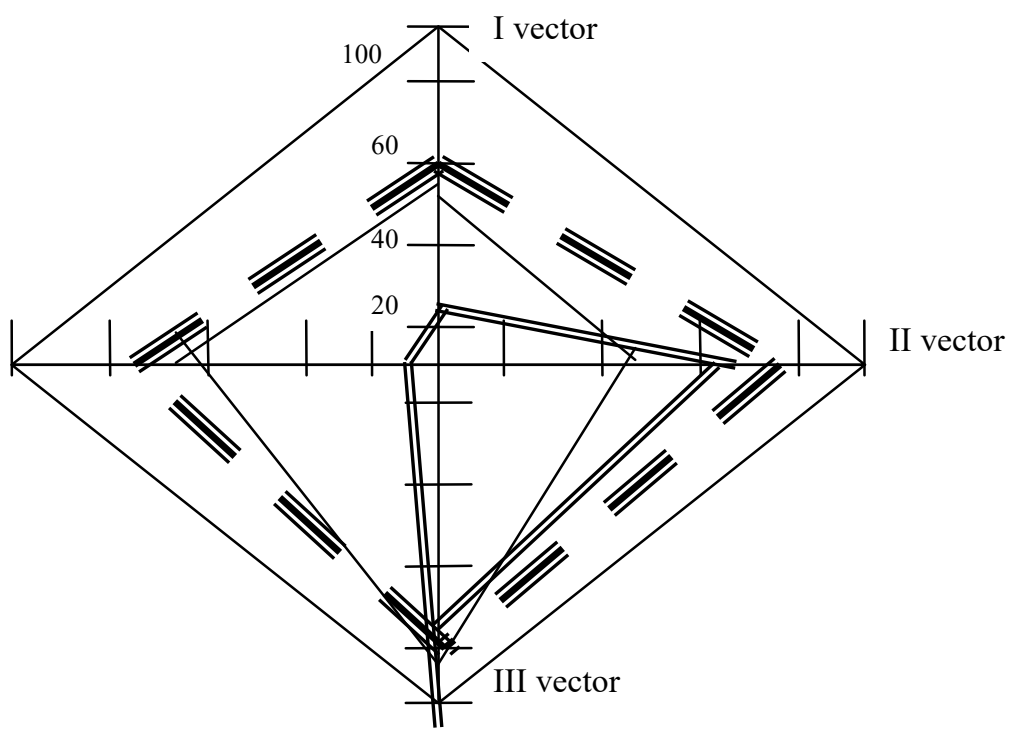

Figure 2. The worst, best and most balanced squares of the potential of the studied subjects

Source: composed by the authors 
are proposed taking into account the marketing tools that young scientists in Ukraine use in their activities, which were identified on the basis of analysis of the results of a mass survey within the framework of the project "Realization of the young scientists' potential in integration of science, education, and business".

\section{Conclusions}

The use of marketing tools contributes to the formation of a positive image of a young scientist in Ukrainian society, thereby demonstrating the competitiveness of domestic science and improving the prospects for commercialization of its potential. It is important to disseminate information about international scientific internships of young scientists and their publications on the results of scientific research, using modern marketing tools. This will not only promote positive communication with society as a whole, but also improve the interaction of young scientists with business, especially those whose developments are of an applied nature.

The authors' hypothesis of the $\mathrm{H}_{1}$ study that digital marketing promotion tools are the most effective marketing tools in the process of strategic human capital management of young scientists has been fully confirmed. In particular, according to a mass sociological survey conducted within the project "Realization of the young scientists' potential in the integration of science, education, and business", an average of $78.5 \%$ of young scientists use participation in conferences and forums as the most effective way to promote information about their own research and development, and at the same time of all respondents use this tool in person only on average only 2-3 times a year, i.e. at other times young scientists prefer the online format using digital technologies.

On average $58.3 \%$ of young scientists have no experience of cooperation with business, also on average $86.4 \%$ of young scientists in Ukraine have no experience of commercialization of rights to the results of their intellectual activity. These results fully confirm the authors' hypothesis $\mathrm{H}_{2}$ that young scientists in Ukraine do not use the marketing tool of cooperation with business for their own promotion and it negatively affects the results of their intellectual activity in the process of strategic management of human capital.

Hypothesis $\mathrm{H}_{3}$ proposed by the authors is partially confirmed. This is related to the fact that popular science articles are indeed one of the most common marketing tools for promoting science among young scientists, but it is not the most effective for all three groups, and for the group of researchers without a degree, the most effective tool for promoting science is their online activity $-36.5 \%$.

As the subject matter of this study, the authors proposed a method for assessing the human potential of a professional group among young scholars, which is a modification of the"Square of Potentials" method of evaluation. The author's modification takes into account four vectors: assessment of the business qualities of educational managers, assessment of the effectiveness of the organizational management structure of scientific and educational institutions, assessment of the overall effectiveness of marketing activities of scientific and educational institutions, the overall assessment of the marketing potential of human development in the strategic management of human capital of scientific and educational institutions. The latter component includes marketing tools identified by the authors as a result of a mass survey of young scientists in Ukraine. This largely reflects the place of marketing tools in the process of strategic management of human capital of young researchers.

Acknowledgements: The publication is prepared within the framework of the young scientists' project "Realization of the young scientists' potential in integration of science, education, and business" (0120U102126) performed at the expense of the general fund of the state budget.

\section{References:}

Bhattacharya, A., Good, V., \& Sardashti, H. (2020). Doing good when times are bad: the impact of CSR on brands during recessions. European Journal of Marketing, 54(9), 2049-2077. DOI: https://doi.org/10.1108/ EJM-01-2019-0088

Council of Young Scientists at the Ministry of Education and Science of Ukraine (CYS at MESU) (2020). Scientific communications of young scientists during the quarantine. Online survey of CYS at MESU. Available at: https://mon.gov.ua/storage/app/media/nauka/rada\%20molodich\%20uchenich/2020/07/ komunikatsii-molodikh-vchenikh-pid-chas-karantinu.pdf

Csapo-Horvath, A. (2021). The importance and influence of destination advertising. European Journal of Sustainable Development, 10(2), pp. 231-240. DOI: https://doi.org/10.14207/ejsd.2021.v10n2p231

Dligach, A. (2014). System-reflexive marketing. Kyiv: Alerta, 400 p.

Fedonin, O. S., Riepina, I. M., \& Oleksiuk, O. I. (2006). Potential of the enterprise: formation and evaluation. Study Book. Kyiv: KNEU, 316 p.

Frolova, L. V., \& Nosova, T. I. (2015). Justification of intellectual potential management strategies of commercial enterprises. Ekonomika ta derzhava, 6, 43-49. Available at: http://www.economy.in.ua/pdf/6_2015/11.pdf 
Gernego, Iu. O. (2020). Financial mechanisms for sustainable human development support: dis. for scientific degree of Dr. Econ. Science: 08.00.08. Kyiv: KNEU, 607 p.

Hoekstra, J. C., \& Leeflang, P. S. H. (2020). Marketing in the era of COVID-19. Italian Journal of Marketing, pp. 249-260. DOI: https:/9doi.org/10.1007/s43039-020-00016-3

Irtyshcheva, I., Trushliakova, A., \& Sirenko, I. (2020). Strategic human capital management in the context of digitalization. Baltic Journal of Economic Studies, 6(5), 178-183. DOI: https://doi.org/10.30525/2256-0742/ 2020-6-5-178-183

Ministry of Education and Science of Ukraine (MESU) (2020). Strategy of higher education development in Ukraine for 2021-2031 years. Available at: https://mon.gov.ua/storage/app/media/rizne/2020/09/25/rozvitkuvishchoi-osviti-v-ukraini-02-10-2020.pdf

Parliament of Ukraine (2015). The Law of Ukraine “On science and scientific-technical activity” № 848-VIII as of 26.11.2015. Available at: https://zakon.rada.gov.ua/laws/show/848-19

Radionova-Girsa, E. (2018). Relationship marketing on the Internet: Building a long-term relationship with customers. In 10th International Scientific Conference "Business and Management 2018", 03-04 May 2018, Vilnius, Lithuania. DOI: https://doi.org/10.3846/bm.2018.35

Reshetnikova, I., Smerichevskyi, S., \& Polishchuk, Y. (2019). Multican marketing as an innovation technology of providing services in the conditions of globalization of the banking market. Marketing and Management of Innovations, 3, 142-150. DOI: http://doi.org/10.21272/mmi.2019.3-11

Rostkowski, T. (2003). Tworzenie i wdrażanie strategii ZZL. Narzędzia i praktyka zarządzania zasobami ludzkimi / M. Juchnowicz (red.). Warszawa: Poltext, pp. 13-15.

Savych, O., \& Shkoda, T. (2020). The concept of marketing efforts consolidation at the global car market. Selected papers of the 11th International Scientific Conference "Business and Management 2020" held on May 07-08, 2020, Vilnius, Lithuania / Edited by J. Stankevičienė, T. Lankauskienė, I. Jokšienė, V. Davidavičienė, I. Skačkauskienè, R. Tamošiūnienė, V. Jurkevičius. Vilnius: “Technika”, 456 p. DOI: https://doi.org/10.3846/ bm.2020.542

Scott, D. M. (2017). The new rules of marketing and PR (7th edition). JAV.

Shkoda, T. N. (2018). Strategic management of human capital of air transport enterprises: dis. for scientific degree of Dr. Econ. Science: 08.00.04; 08.00.07. Kyiv: KNEU, 586 p.

State Statistical Service of Ukraine (2020). Number of young scientists in Ukraine. Official on-line answer to the request as of 29.01.2020. Kyiv.

Sturiene, U. (2019). Internet Marketing Tools. 14th Prof. Vladas Gronskas International Scientific Conference Kaunas: Vilnius University Kaunas Faculty, 5th of December, 2019. Available at: https://www.journals.vu.lt/ open-series/article/view/18406

Zhabin, S. O., Isakova, N. B., \& Skorokhod, O. M. (2018). Problems of young scientists of Ukraine and recommendations for their solution. Analytical material. Available at: https://www.civic-synergy.org.ua/ wp-content/uploads/2018/04/Problemy-molodyh-vchenyh-Ukrayiny-ta-rekomendatsiyi-shhodo-yihnogovyrishennya.pdf?fbclid=IwAR0OPqjUJ3hqGT-1PFN8jExnoKtCGs8JdxguMsovjzKlR0uUzCHs_8pj3Pw 